\title{
Assessment of Groundwater Quality and Saline Intrusions in Coastal Aquifers of Lagos Metropolis, Nigeria
}

\author{
Adewuyi Gregory Olufemi ${ }^{1^{*}}$, Oputu Ogheneochuko Utieyin ${ }^{2}$, Opasina Mukaila Adebayo ${ }^{3}$ \\ ${ }^{1}$ Department of Chemistry, University of Ibadan, Ibadan, Nigeria \\ ${ }^{2}$ Department of Chemical Sciences, Olabisi Onabanjo University, Ago-Iwoye, Nigeria \\ ${ }^{3}$ Oyo State College of Education, Eruwa Campus, Eruwa, Nigeria \\ E-mail: adewuyio@yahoo.co.uk \\ Received July 1, 2010; revised September 3, 2010; accepted September 18, 2010
}

\begin{abstract}
As a result of immense industrialisation and high population growth, groundwater is heavily relied on in Lagos metropolis to serve as an alternative source of water where surface water is seriously polluted. The continued reliance on ground water has resulted in its decline in quantity and quality. In this study, the coastal aquifers of Lagos metropolis were selected for an assessment of its groundwater quality and impact of saline intrusion. Water samples collected along the coastal region were subjected to various physicochemical analyses. Results obtained were compared with permissible values for drinking water stated by Federal Environmental Protection Agency (FEPA) and World Health Organization (WHO). The results revealed that all the water samples were significantly hard (range $522.14-1233.34 \mathrm{mg} / \mathrm{L}$ ). The salinity was delineated by conductivity measurements. Three samples had specific conductance above the stated limits for fresh water. The samples however met the stipulated limits for drinking water for the other tested parameters.
\end{abstract}

Keywords: Industrialisation, Groundwater, Physiochemical Analysis, Salinity, Conductivity

\section{Introduction}

Groundwater has long served as a source of drinking water and it is still very important today. The development of ground water has provided great socio-economic benefits to humanity. Globally, groundwater is estimated to provide about $50 \%$ of current drinking water supplies. As groundwater is isolated from the surface, most people take it for granted that groundwater should be relatively pure and free from pollutants. Although most groundwater are still of high quality, at some locations, it is becoming increasingly difficult to maintain the purity of groundwater. One of the major sources of pollution of groundwater is by saltwater intrusions. Others include seepages from underground storage tanks, oil wells, septic tanks, land fills and agricultural leaching.

Saline intrusions into coastal groundwater via aquifer penetration have become a major concern [1] because it is the commonest source of pollution to groundwater. The extent of saltwater intrusions into groundwater is dependent on several natural and anthropogenic factors; the nature of the aquifer and its natural recharge rates being the major natural factors. The anthropogenic fac- tors include excessive groundwater withdrawals [1-6] and lack of sealing of abandoned boreholes and oil wells. Studies have indicated that increased groundwater salinity may be due to clearing of natural forests resuslting in enhanced recharges which leaches salt downwards from salt stored in the unsaturated zone [7] or causes the water to rise dissolving salt as it does so [8]. The pollution of shallow aquifers under cities represents a major treat to sustainability of drinking water supplies in many urban areas throughout the world [4,9]. Frohlich and Urish [10] reported that the deterioration of the freshwater quality due to natural sea water infiltration affects the balanced life of the coastal strip of Rhodes Island. The present study was conducted in Lagos State in South western Nigeria, boarded in the south by the Atlantic ocean, in the north and east by Ogun state and in the west by Republic of Benin. It occupies an area of about $3.577 \mathrm{sq} \mathrm{km}$ with a population of about 14 million. $80 \%$ of the population resides in the metropolitan Lagos, making the state the most urbanized in Nigeria [11].

The aquifer structure of Lagos state falls in the Benin basin where salt water intrusion into the recent sediments aquifers occurs beneath the fresh water lens [12]. These 
intrusions of salt water from the Atlantic ocean have caused untold hardship to habitats of the coastal areas of the state. There is an increasing pressure on the ground water reserves of the state as a result of massive influx of people from other parts of Nigeria to Lagos metropolis (rural to urban migration). Longe et al. [13], estimate that about 10 million gallons of water are extracted from the multilayer aquifers areas per day. Most of the bore holes drilled in the areas of Lagos have been abandoned due to salt water intrusions into the aquifer

The federal and state water agencies have initiated several hydrogeological evaluation of its groundwater resources $[14,15]$. However, the extent of groundwater intrusions and nature of these intrusions still require further investigations [16].

The objective of the present study is to ascertain the groundwater quality along the coastal region of Lagos state and assess the extent of saline intrusions in coastal aquifers of Lagos metropolis. Sampling sites were identified along the coastal line and groundwater samples were collected and subjected to physicochemical analysis.

\section{Materials and Methods}

\subsection{Sampling}

Groundwater samples were collected from eight (8) different sites (wells) along the coastal areas of Lagos metropolis. The wells were pumped for ten (10) minutes before samples were collected to ensure representative sampling. Plastic containers used for collection of samples were pre-treated by washing with $0.05 \mathrm{M} \mathrm{HCl}$ and then rinsed with distilled water [17]. After collection, sample bottles were tightly covered and transported un$\operatorname{der} 4^{\circ} \mathrm{C}$ to the laboratory for chemical analysis. The location of sampling sites is shown in Figure 1. The global positioning coordinates as well as relief features of the sites are shown in Table 1.

Refrigerated samples were allowed to attain room temperature prior to chemical analysis. Fast changing parameters such as $\mathrm{pH}$, temperature and electric conductivity were determined insitu. Temperature was measured using a mercury thermometer (range $0^{\circ} \mathrm{C}$ to $100^{\circ} \mathrm{C}$ ), $\mathrm{pH}$ was measured using a pre-calibrated $\mathrm{pH}$ meter. Electrical

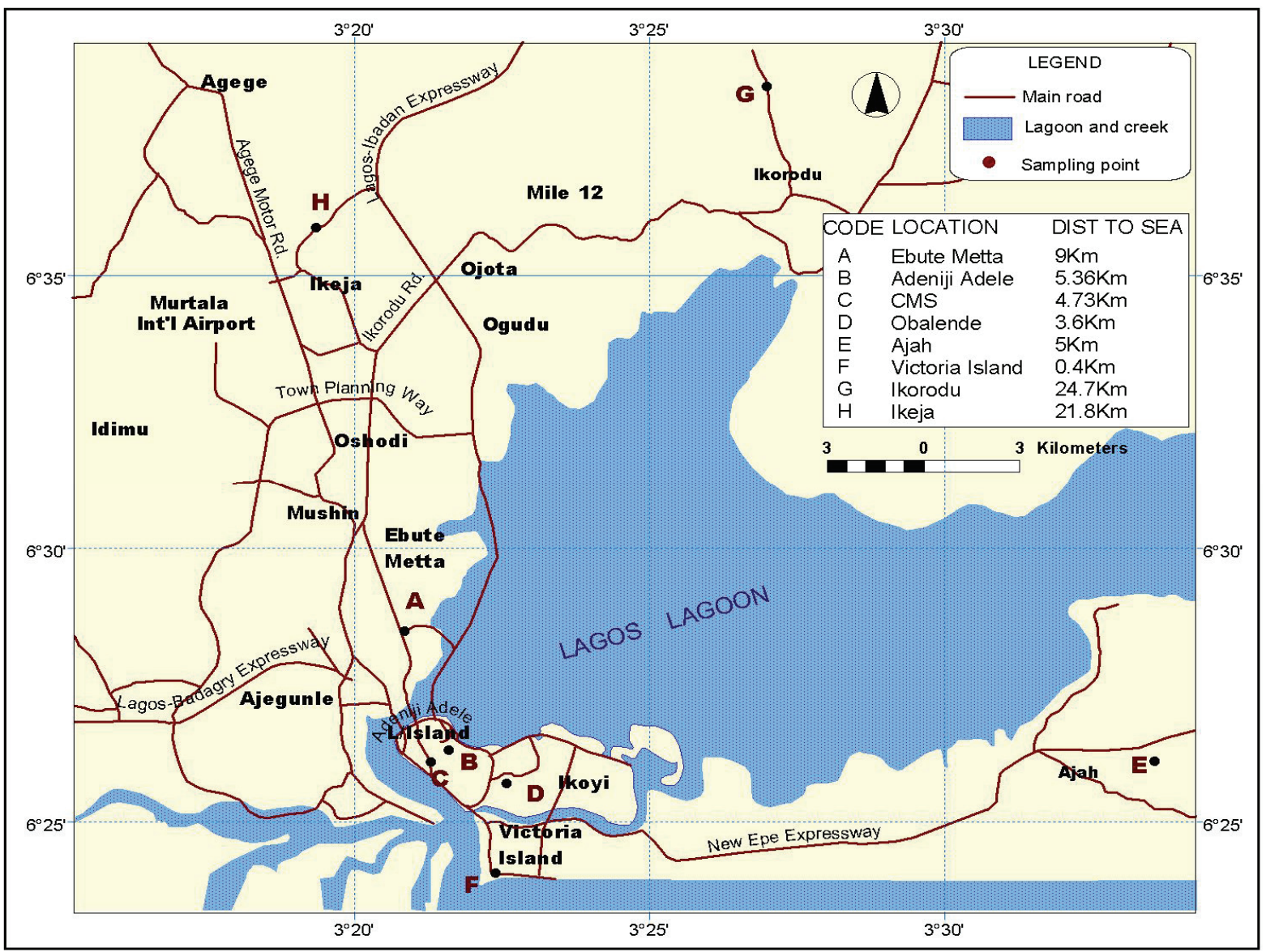

Figure 1. Map showing sampling points. Code A-H refers to points on the map. 
Table 1. Showing sampling points, GPS coordinates and relative positions from the ocean.

\begin{tabular}{|c|c|c|c|c|c|}
\hline Location & Code & Elevation (ft) & Dist. from ocean (m) & Latitude ( ${ }^{\circ}$ North) & Longitude $\left(^{\circ}\right)$ \\
\hline Adeniji Adele & AA & 52 & 3600 & 6.4572 & 3.3961 \\
\hline Ajah & $\mathrm{AJ}$ & 57 & 2470 & 6.4686 & 3.5924 \\
\hline CMS & CMS & 68 & 2180 & 6.4541 & 3.3902 \\
\hline Ebutte Metta & EBM & 77 & 9000 & 6.4903 & 3.3813 \\
\hline Ikeja & IKJ & 91 & 4730 & 6.6065 & 3.3482 \\
\hline Ikorodu & $\mathrm{IKO}$ & 102 & 5000 & 6.6411 & 3.4806 \\
\hline Obalende & OBA & 116 & 5360 & 6.4489 & 3.1482 \\
\hline Victoria Island & VIL & 23 & 400 & 6.4211 & 3.4806 \\
\hline
\end{tabular}

conductivity (specific conductance) was measured using a Horiba U90 meter with an accuracy of $0.001 \mu \mathrm{s} / \mathrm{cm}$. Total dissolved solids, total hardness, sulphate, alkalinity and chloride were determined by standard methods [17, 18]. Alkali metals - sodium and potassium was determined by flame absorption spectrophotometry. All reagents used for analysis were prepared from analar grade chemicals. Appropriate reagent blanks were prepared for each analysis. All analysis was done in triplicates.

\section{Results and Discussion}

The results obtained from the analyses of ground water samples collected revealed that some of the tested parameters fall within the permissible limits stipulated by FEPA (Federal Environmental Protection Agency) [19] and WHO (World Health Organization) [20]. The pH, sulphate $\mathrm{SO}_{4}{ }^{2-}$, phosphate $\mathrm{PO}_{4}{ }^{3-}$, hardness due to calcium and alkalinity fall within the accepted values for drinking water as shown by the results in Table 2 and standards for FEPA and WHO in Table 3 and Table 4 respectively.

The total hardness of all the water samples however exceeds the permissible limits stated by the controlling agencies (refer to Tables 2, 3 and 4). The total hardness is a measure of contributions from calcium, magnesium, and other polyvalent cations such as iron, zinc, manganese, aluminium, and strontium. The low contribution of calcium to the total hardness may be suggestive of an absence of calcium bearing mineral from the underlying aquifer. The high values of total hardness may be due to the introduction of polyvalent cations into the groundwater system. All the water samples may be regarded as 'very hard' (hardness $>300 \mathrm{mg} / \mathrm{L}$ ) according to the classification for hardness [18].

The chloride concentration measured for the samples did not exceed the limit set by WHO and FEPA (250 $\mathrm{mg} / \mathrm{L}$ ). Chloride is not considered harmful to humans, but imparts a salty taste to water above this limit. The high chloride concentration recorded in this study may however cause harm to plants if used for irrigation purposes. Chloride concentrations as high as $70 \mathrm{mg} / \mathrm{L}$ have been reported to cause damage to plant tissues [18]. The concentration of alkali metals sodium and potassium varied widely. Sodium concentrations ranged from 46.78 $\mathrm{mg} / \mathrm{L}$ for Ebutte Metta to $490 \mathrm{mg} / \mathrm{L}$ for Victoria Island. Potassium concentrations ranged from $8.67 \mathrm{mg} / \mathrm{L}$ for Ebutte Metta to 341.70 for Victoria Island. The correlation $\mathrm{R}^{2}(0.759)$, for both ions though weak is suggestive of identical sources for both ions.

Conductivity measurement is widely used as substitute for total dissolved solids (TDS) and salinity determinations. Adekunle [19] used resistivity method (inverse of conductivity) to delineate salt water intrusions into fresh water aquifer of Lekki Peninsula, Lagos, Nigeria. The data obtained for conductivity measurements in this study ranged from $126 \mu \mathrm{s} / \mathrm{cm}$ for Ikeja to $1565 \mu \mathrm{s} / \mathrm{cm}$ for Victoria Island. Permissible values for conductivity for drinking water is $1000 \mu \mathrm{s} / \mathrm{cm}$. Values exceeding this limit are indicative of saline intrusions into the groundwater. Water samples collected from Adeniji Adele (1251.2 $\mu \mathrm{s} / \mathrm{cm})$, CMS $(1520.0 \mu \mathrm{s} / \mathrm{cm})$ and Victoria Island (1565.2 $\mu \mathrm{s} / \mathrm{cm})$ exceed the permissible value and could be under threat of saline pollution. The intrusions gradual intrusion of saline water into the groundwater for Adeniji Adele, CMS and Victoria Island may be attributed to their relative closeness to the Atlantic Ocean and their elevation from sea level. Data on relative elevation and distance from sea level is shown in Table 1. The groundwater in Victoria Island is under stress due to pollution from saline waters. Characteristic features of the area include: close proximity to the ocean, low elevation from sea level, poor aquifer structure (belonging to the Benin basin where salt water bearing sand overlie fresh water [12]. Adekunle [19]; Oteri and Atolagbe [12] have previously reported cases of saline intrusions occurring in Lekki Peninsula which is separated from Victoria Island by Falomo River. Obalende which has the highest eleva- 
Table 2. Showing mean results of physico-chemical analyses of samples.

\begin{tabular}{|c|c|c|c|c|c|c|c|c|c|c|}
\hline Code & $\mathrm{pH}$ & $\begin{array}{c}\left(\mathrm{SO}_{4}\right)^{2-} \\
\mathrm{mgLL}\end{array}$ & $\begin{array}{c}\left(\mathrm{PO}_{4}\right)^{3-} \\
\mathrm{mgL}\end{array}$ & $\begin{array}{c}\mathrm{Ca} \\
\text {-Hardness } \\
\mathrm{mg} L\end{array}$ & $\begin{array}{c}\text { Total } \\
\text { Hardness } \\
\text { mgL }\end{array}$ & $\begin{array}{c}\mathrm{Cl}^{-} \\
\mathrm{mgL} L\end{array}$ & $\begin{array}{c}\mathrm{Na}^{+} \\
\mathrm{mgL}\end{array}$ & $\underset{\mathrm{mg} L}{\mathrm{~K}^{+}}$ & $\begin{array}{l}\text { Electric. } \\
\text { Cond. } \\
\mu \mathrm{s} / \mathrm{cm}\end{array}$ & $\begin{array}{l}\text { TDS } \\
\mathrm{mg} / \mathrm{L}\end{array}$ \\
\hline $\mathrm{AA}$ & 6.01 & 34.91 & 0.01 & 120.9 & 1090.25 & 94.3 & 232.82 & 86.67 & 1251 & 625.50 \\
\hline $\mathrm{AJ}$ & 6.38 & 29.68 & ND & 89.24 & 998.56 & 61.28 & 156.99 & 36.01 & 407 & 203.51 \\
\hline CMS & 6.68 & 63.4 & ND & 121.2 & 1233.34 & 58.2 & 483.42 & 193.2 & 1520 & 760.01 \\
\hline EBM & 6.76 & 24.28 & 0.03 & 27.98 & 522.14 & 22.33 & 46.78 & 8.67 & 130 & 65.05 \\
\hline IKJ & 6.59 & 32.62 & ND & 41.73 & 526.14 & 19.01 & 56.15 & 10.91 & 126 & 63.31 \\
\hline IKO & 6.45 & 32.71 & ND & 47.32 & 890.53 & 28.98 & 91.99 & 20.46 & 288 & 144.13 \\
\hline OBA & 5.93 & 44.07 & ND & 148.76 & 1131.46 & 92.16 & 311.24 & 92.88 & 940 & 470.00 \\
\hline VIL & 6.63 & 42.13 & ND & 119.2 & 926.25 & 109.5 & 430.07 & 341.7 & 1565 & 782.51 \\
\hline
\end{tabular}

Table 3. Federal Environmental Protection Agency (FEPA) now Federal Ministry of Environment - water quality criteria (FEPA, 1988).

\begin{tabular}{ccc}
\hline Parameter & Permissible criteria $(\mathrm{mg} / \mathrm{L})$ & Desirable criteria $\mathrm{mg} / \mathrm{L}$ \\
\hline Colour & 75 & $<10$ \\
Odour & Virtually absent & Virtually absent \\
Turbidity & 25 Turbidity unity & Nil \\
$\mathrm{pH}$ & $6.0-8.5$ & $6.0-8.5$ \\
Alkalinity $\mathrm{CaCO}_{3}$ & $30-500$ & $30-500$ \\
$\mathrm{Cl}^{-}$ & 2.5 & $<2.5$ \\
$\mathrm{SO}_{4}{ }^{2-}$ & 250 & $<50$ \\
$\mathrm{TDS}_{\mathrm{PS}}$ & 500 & 500 \\
\hline
\end{tabular}

Table 4. World Health Organisation (WHO) standards for drinking water (WHO, 1971).

\begin{tabular}{cc}
\hline Parameter & Maximum permissible limit \\
\hline Turbidity & 25 turbidity units \\
$\mathrm{pH}$ & $6.5-9.2$ \\
Total solids & $1500 \mathrm{mg} / \mathrm{L}$ \\
Total Hardness & $500 \mathrm{mg} / \mathrm{L}$ \\
Hardness-Ca & $200 \mathrm{mg} / \mathrm{L}$ \\
$\mathrm{Cl}^{-}$ & $600 \mathrm{mg} / \mathrm{L}$ \\
$\mathrm{SO}_{4}{ }^{2-}$ & $400 \mathrm{mg} / \mathrm{L}$ \\
\hline
\end{tabular}

Table 5. Assessment of water samples based on the stipulated limits.

\begin{tabular}{cccccccc}
\hline Location & $\mathrm{pH}$ & $\mathrm{SO}_{4}{ }^{2-}$ & $\mathrm{PO}_{4}{ }^{3-}$ & Hardness-Ca & $\mathrm{Cl}^{-}$ & $\begin{array}{c}\text { Total Hard- } \\
\text { ness }\end{array}$ & $\begin{array}{c}\text { Electric. Conduc- } \\
\text { tivity }\end{array}$ \\
\hline $\mathrm{AA}$ & + & + & + & + & + & - & - \\
$\mathrm{AJ}$ & + & + & + & + & + & - & + \\
$\mathrm{CMS}$ & + & + & + & + & + & - & - \\
$\mathrm{EBM}$ & + & + & + & + & + & - & + \\
$\mathrm{IKJ}$ & + & + & + & + & + & - & + \\
$\mathrm{IKO}$ & + & + & + & + & + & - & + \\
OBA & + & + & + & + & + & - & + \\
VIL & + & + & + & + & + & - & - \\
\hline \\
+ meets the stipulated permissible limits \\
fails to meet the stipulated permissible limits
\end{tabular}


tion from sea level (Table 5) still has high electrical conductivity. This may be attributed to the area's close proximity to the ocean $(3.6 \mathrm{Km})$ as compared to values for the other sites.

\section{Conclusions}

Conclusively, at present there is no universal system for classification of groundwater systems. Several agencies such as the Rhode Island department of environmental management office of water resource have classified groundwater based on its suitability for drinking with or without pre-treatment. The assessment of groundwater for Lagos state adopted in this study is based on whether the water meets all the requirements as stated by FEPA and WHO. The result from this study revealed that all the water samples analysed were hard and three did not meet the standard for conductivity. The water samples however met the permissible limits for drinking water for $\mathrm{SO}_{4}{ }^{2-}, \mathrm{PO}_{4}{ }^{3-}, \mathrm{Cl}^{-}, \mathrm{pH}$ and hardness due to calcium.

\section{Acknowledgements}

The Authors wish to thank the Department of Chemistry University of Ibadan for providing some of the materials in carrying out the study. Also, the assistance received from Mrs. Ronke Abdulwaheed, Mrs. Fadeke Opeseitan and Pastor Dipo Ayodele during collection and analysis of samples is acknowledged.

\section{References}

[1] A. T. Batayneh, "Use of Electrical Resistivity Methods for Detecting Subsurface Fresh a Saline Water and Delineating their Interfacial Configuration: A Case Study of the Eastern Dead Sea Coastal Aquifers," Jordan Hydrogeology Journal, Vol. 14, No. 7, 2006, pp. 1277-1283.

[2] J. O. Oseji and O. Ujuanbi, "Hydrogeophysical Investigation of Groundwater potential in Emu kingdom, Ndokwa land of Delta State, Nigeria," International Journal of Physical Sciences, Vol. 4, No. 5, 2009, pp. 275-284.

[3] J. Y. Lee and S. H. Song, "Evaluation of Groundwater Quality in Coastal Areas: Implications for Sustainable Agriculture" Environmental Geology, Vol. 52, No. 7, 2007, pp. 1231-1242.

[4] K. Choudhury, D. K. Saha and P. Chakraborty, "Geophysical Study for Saline Water Intrusion in a Coastal Alluvial Terrain," Journal of Applied Geophysics, Vol. 46, No. ER4, 2001, pp. 189-200.

[5] R. K. Frohlich, D. W. Urish, J. Fuller and M. O. Reilly,
"Use of Geoelectrical Method in Groundwater Pollution Surveys in a Coastal Environment," Journal of Applied Geophysics, Vol. 32, No. 2-3, 1994, pp. 139-154.

[6] D. W. Urish and R. K. Frohlich, "Surface Electrical Resistivity in Coastal Groundwater Exploration," Geoexploration, Vol. 26, No. 4, 1990, pp. 267-289.

[7] F. W. Leaney, A. L. Herizeg and G. R. Walker, "Salinization of a Fresh Paleo-Groudwater Resource by Enhanced Recharge," Groundwater, Vol. 41, No. 1, 2003, pp. 84-90.

[8] P. G. Macumber, "Interaction between Groundwater and Surface Systems in Northern Victoria," Department of Conservation and Environment, Victoria, 1991.

[9] World Health Organization, "Guidelines for Drinking Water Quality,” W.H.O., Geneva, 1993, p. 188.

[10] R. K. Frohlich and D. W. Urish, "The Use of Geoelectrics and Test Wells for the Assessment of Groundwater Quality of a Coastal Industrial Site," Journal of Applied Geophysics, Vol. 50, No. 3, 2002, pp. 261-278.

[11] E. O. Longe and A. Williams, "A Preliminary Study of Medical Waste Management in Lagos Metropolis, Nigeria," Iranian Journal of Environmental Health, Science and Engineering, Vol. 3, No. 2, 2006, pp. 133-139.

[12] A. U. Oteri and F. P. Atolagbe, "The Second International Conference on Saltwater Intrusion and Coastal Monitoring, Modelling, and Managenent," Merida, Yucatan, Mexico, 2003.

[13] E. O. Longe, S. Malomo and M. A. Olorunniwo, "Hydrogeology of Lagos Metropolis," African Journal of Earth Sciences, Vol. 6, No. 2, 2007, pp. 163-174.

[14] K. Kruger and S. Associates, "Underground Water Resources of the Metropolitan Lagos," Final Report to Lagos State Ministry of Works, Lagos, 1997, p. 170.

[15] Coode Blizard Ltd., Akute Geo-Resource Ltd. and Rofe Kennard \& Lapworth, "Hydrogeological Investigation of Lagos State," Final Report, Vol. 1 \& 2, 1996.

[16] UNESCO, "World-Wide Hydrogeological Mapping and Assessment Programme (WHYMAP)," 4th World Water Forum, Mexico City, March 2006.

[17] APHA, "Standard Methods for the Examination of Water and Wastewater," America Public Health Association, 18th Edition, New York, 1992.

[18] M. Radojevic and V. Bashkin, "Practical Environmental Analysis," The Royal Society of Chemistry, Cambridge, 1999.

[19] FEPA, "Present Water Quality Status in Nigeria," Federal Environmental Protection Agency, Lagos, 1998, pp. 3541.

[20] World Health Organization, "International Standards for Drinking Water,”2nd Edition. W.H.O., Geneva, 1971. 